\title{
Intermédialités
}

Histoire et théorie des arts, des lettres et des techniques

Intermediality

History and Theory of the Arts, Literature and Technologies

\section{Hitler's Voice}

\section{The Loudspeaker under National Socialism}

\section{Cornelia Epping-Jäger}

Numéro 17, printemps 2011

reproduire

reproducing

URI : https://id.erudit.org/iderudit/1005750ar

DOI : https://doi.org/10.7202/1005750ar

Aller au sommaire du numéro

Éditeur(s)

Revue intermédialités (Presses de l’Université de Montréal)

ISSN

1705-8546 (imprimé)

1920-3136 (numérique)

Découvrir la revue

Citer cet article

Epping-Jäger, C. (2011). Hitler’s Voice: The Loudspeaker under National Socialism. Intermédialités / Intermediality, (17), 83-104.

https://doi.org/10.7202/1005750ar
Résumé de l'article

Cet article se propose d'étudier les mécanismes par lesquels le national-socialisme a imposé un pouvoir acoustico-politique. Il s'intéresse à un médium technique, le haut-parleur, que les nazis ont utilisé dans un but de très large communication, en tant qu'appareil constitutif de leur culture politique. Ainsi, différents scénarios opératoires impliquant le haut-parleur en rapport avec les nouveaux développements spatio-acoustiques sont analysés. Les speakers nazis, et Hitler en particulier, performaient dans un cadre technique et médial. L'article cherche à mettre en lumière la temporalité du travail de restructuration qui donnait consistance à leurs voix. 


\title{
Hitler's Voice
}

\section{The Loudspeaker under National Socialism}

\author{
Cornelia Epping-Jäger
}

\begin{abstract}
And so the National Socialist revolution unfolded: the Führer's breath swept across the heap of corpses at Weimar and brought the dry bones to life. One here, one there, a long row until, finally, the entire German people was rising from its grave, awoken by the voice of its prophet. ${ }^{1}$
\end{abstract}

omposed in 1934, Karl Kindt's ghostly praise of a prophetic "Führer's breath" - the voice of National Socialism-contains, in particular, one faulty claim amongst several: it was never the "charismatic orality" of the Führer's voice which, through its rhetorical nakedness, spoke "from the heart to the hearts of listeners," to take up a formulation by Hugo Ringler, a member of the Reichspropaganda division of the NSDAP (Nationalsozialistische Deutsche Arbeiterpartei). ${ }^{3}$ Similarly, it also never was the breath, approached through its affective eidetic ground, ${ }^{4}$ which addressed the "people in its entirety," ${ }^{5}$ though these addresses did occur with notable success. Thus, the political voice of the

1"Ja, so verlief die nationalsozialistische Revolution. Der Atem des Führers ging hin über das Leichenfeld von Weimar und machte die Totengebeine lebendig, hier einen, dort einen, eine lange Reihe, zuletzt das ganze Volk; aus dem Grabe stieg Deutschland, erweckt von der Stimme seines Propheten." Karl Kindt, Der Führer als Redner, Hamburg, Hanseatische Verlagsanstalt, 1934, p. 7-8 (my translation).

2"Charismatische Mündlichkeit." Claudia Schmölders, "Stimmen von Führern. Auditorische Szenen 1900-1945," in Friedrich Kittler, Thomas Macho and Sigrid Weigel (eds.), Zwischen Rauschen und Offenbarung. Zur Kultur- und Mediengeschichte der Stimme, Berlin, Akademie Verlag, 2002, p. 175-195 (my translation).

3. "Aus dem Herzen zu den Herzen der Zuhörer." Hugo Ringler, "Herz oder Verstand? Was wir vom Redner nicht wollen," in Unser Wille und Weg, vol. 7, 1937, p. 245 (my translation).

4. Horst Gundermann, "Das Phänomen Stimme," in Die Ausdruckswelt der Stimme. 1. Stuttgarter Stimmtage, Heidelberg, Hüthig, p. 4.

5. "Das Volk in seiner Gesamtheit." Ringler, 1937, p. 245 (my translation). 
NS (Nationalsozialismus) did not rely on rhetorical nakedness or communicational immediacy for effectiveness. Instead, its efficacy arose from the voice's acoustic presence which, in turn, facilitated successful direct address and gave rise to a form of presence resulting, naturally, from medial orchestration.

Within the self-definition of the NS, the political orator was represented as a figure "illuminated and filled with the glorious ideas and positions of the National Socialist worldview." Standing before his audience, the speaker's task lay in the "transmission of the enthusiasm, dedication and faith, which he carried within himself, onto his listeners." ${ }^{7}$ In reality, however, the rhetorical impact of these addresses, if it occurred at all, was due less to a sense of pathos, which would have arisen from their authenticity, than to a highly differentiated communicational choreography which was being developed through a complex and increasingly sophisticated staging apparatus.

By virtue of its structure and the history of its emergence, the NSDAP can be characterized as a "speakers' party." In both its tendency toward inner consolidation and its outwardly directed political effectiveness, it is a fundamentally phonocentric party - a party which was organized, primarily, around the acoustic resonance of voices. In 1928 at the latest, the NSDAP would be the sole party to draw from the growingly differentiated medial configuration which I have come to term "loud/speaker." This device incorporated both the publicly distributed Führer's voice and its multiple ersatz-voices. It combined the technical apparatus (microphone/loudspeaker/amplifier), the voices of the speakers and their rhetorical and ideological armours, as well as the communicational scenarios of their own incorporation into mass public events such as radio broadcasting. Thus, the function of the loud/speaker apparatus consisted, first and foremost, in its internalization of the community-forming power of the acoustic experience. Within this experience, the community constructed itself in medial terms through the ubiquity of the Führer's voice and its resonance across society.

\section{PHONOCENTRISM: THE NSDAP AS a “SPEAKERs' PARTY”}

1925 marked the year of the party's re-constitution wherein "the voice" was to play a leading role as an instrument of propaganda. In Mein Kampf, Hitler states: "we want to push propaganda to its utmost extremes. We want to create a wave of

6. "[D]urchglüht und bis ins innerste erfüllt von dem herrlichen Ideengut und der Gedankenwelt der nationalsozialistischen Weltanschauung.” Ibid., p. 245.

7. "[D]iese Begeisterung und diese Hingabe und diesen Glauben, die er in sich trug, auf seine Zuhörer zu übertragen." Ibid., p. 245. 
indignation and to send hundreds of speakers amongst the people." ${ }^{8}$ Hitler was highly interested in the results of advertising psychology. ${ }^{9}$ According to him, propaganda's central purpose would be to "pave the way for the party by identifying and winning over 'human material'." ${ }^{10}$ Within this logic, the NSDAP was the first party of the Weimar Republic to create a commission dedicated to the propagandistic recruitment of members through the acoustic power of voices. Certainly, this was closely tied to the centrality attributed to the oratory powers of Adolf Hitler himself. To the contemporary listener, Hitler's voice might sound uncanny in its excessive display of affectivity. However, for NS party members, its staged authenticity provided an apt example of what Goebbels termed an "entirely new style of political speech."11 A style which, to its followers, suggested honesty and unconditional investment by differentiating itself from the then-widespread tone of established political figures. Thereby, it laid the ground for the emergence of the party's phonocentric model of propaganda.

This development, which had emerged over the years, only increased after 1925 through the organization and deployment of speakers in view of increasing public activity. While the party only had 70 speakers at its disposal in May of 1926, the Völkische Beobachter counted 2370 mass meetings and 3500 "speaker evenings" (Sprechabende) by 1927 and a total of 20,000 meetings in the following year. By 1928 , which marked the year of the NSDAP's inception as a "mass party," there were 300 official speakers in the party. ${ }^{12}$ According to the party's own sources, more than 30,000 rallies were organized for the presidential elections in the spring of 1932. ${ }^{13}$

8. "Wir wollen die Propaganda bis zum äußersten steigern. Wir wollen eine Welle der Empörung schaffen und Hunderte von Rednern hinaus ins Volk schicken." Adolf Hitler, Mein Kampf, München, Zentralverlag der NSDAP F. Eher Nachf., 1939, p. 417418 (my translation).

9. Sabine Behrenbeck, "Der Führer. Die Einführung eines politischen Markenartikels," in Gerald Diesener and Rainer Gries (eds.), Propaganda in Deutschland. Zur Geschichte der politischen Massenbeeinflussung im 20. Jahrhundert, Darmstadt, Primus, 1996 , p. 51-78.

10. "[D]er Organisation weit voraneilen und dieser erst das zu bearbeitende Menschenmaterial gewinnen [müsse]." Ibid. (my translation).

11. "[G]anz neuen Stils der politischen Rede." Joseph Goebbels, Kampf um Berlin 1, Der Anfang, 1926-1927, Munich, Eher Verlag, 1932, p. 46 (my translation).

12. Detlef Grieswelle, Propaganda der Friedlosigkeit. Eine Studie zu Hitlers Rhetorik 1920-1933, Stuttgart, Ferdinand Enke Verlag, 1972, p. 27.

13. Eugen Hadamovsky, Propaganda und nationale Macht. Die Organisation der öffentlichen Meinung für die nationale Politik, Oldenburg, Gerhard Stalling Verlag, 1933, P. 44. 
Finally, by 1933 , the number of speakers had tripled with 1000 speakers completing over 34,000 election rallies that very year. ${ }^{14}$ Those speakers had been trained in so-called "speaker schools" which, in accordance with the newest principles of effective labour organization, also offered correspondence courses. These relied on a range of materials which combined background information pertaining to political events with argumentational tools. Thus, through a combination of large-scale events and speaker evenings, where party members received feedback on specific issues from fellow members, the NSDAP was able to earn the longterm loyalty of its members. ${ }^{15}$

Those appearances were coordinated by the Reichspropagandaleitung (RPL), under the direction of Himmler and subsequently Goebbels. The appointed Amt 1 of the RPL, standing for Aktive Propaganda, Hauptstelle Rednerwesen, had the task of "organizing all propaganda-related events from mass meetings [...] to local groups" as well as distributing speakers for these events across the territory of the Reich. Amt IV, standing for Kultur, Hauptstelle Programmgestaltung, was responsible for the conceptualization of "program mockups for NS festivities and for the creation of a framework for NS announcements in accordance with previously established aesthetic parameters." 16 Finally, all events and experiencesin particular those regarded as "disruptive" - were systematically assessed and archived by the Hauptstelle Kultur, which retained a large selection of sample choreographies for future mass meetings in its institutional memory. ${ }^{17}$

In 1934, the phonocentric model underwent one last transformation before adopting the final, stable form it would maintain until 1945. Starting in 1934, a hierarchy was developed, wherein Reichsredner, Stoßtruppredner, Gau- and Kreisredner were regrouped under the authority of the Rednerorganisation. Then, after having received the party's educational and informational material from the Rednerinformation office, they were dispatched by the Rednervermittlung division. Finally, the Rednerschulung division, which had its own speaker school

14. Gerhard Paul, Aufstand der Bilder. Die NS-Propaganda vor 1933, Bonn, Verlag J. H. W. Dietz Nachf., 1990, p. 125. See also Grieswelle, 1972, p. 29.

15. Bundesarchiv, Berlin, Section NS 22/904.

16. “[D]er organisatorischen Durchführung aller anfallenden Propagandaaktionen von der Großveranstaltung [...] bis zur Durchführung der Veranstaltungen der Ortsgruppen" and "Beispielprogrammen für Feiern der nationalsozialistischen Bewegung und für die Rahmengestaltung nationalsozialistischer Kundgebungen auf der Grundlage der gewonnenen Gestaltungstraditionen.” Karlheinz Schmeer, Die Regie des öffentlichen Lebens im Dritten Reich, München, Pohl Verlag, 1956, p. 30 (my translation).

17. Bundesarchiv, Section NS 22/904. 
(Reichsrednerschule), provided the speakers with equipment and future generations to be trained. ${ }^{18}$

This process marks a clear turn towards the party's perfecting and expanding of its use of voices. In turn, this use mirrored the NSDAP's self-description as a "socially revolutionary movement," which drew its rapid centrifugal acceleration from its very own phono-center. The propagandistic use of speakers pursued the intertwined aim of effectively addressing the public and of promoting a new organizational structure, which in turn served the purpose of generating more propaganda. In Mein Kampf, Hitler wrote: "Propaganda's central aim is to win over people for the organization; the central aim of the organization is to win over people for the continuation of propaganda." ${ }^{19}$

The speakers' voices could never be allowed to die down as their effect held no lasting power and thus, in the manner of a continuously working machine, the Reichspropaganda took on the task of multiplying them. If propaganda is the "art of community formation," in the words of Eugen Hadamovsky, NS-Propagandist, and if it is, indeed, an art dependent on emotion rather than content, then the "silencing of the voice presents a direct menace to the existence of the community of listeners." ${ }^{20}$ In other words, the NS movement was able to construct and perpetuate itself as movement through speech, by fuelling itself steadily through its mass mobilizing voice-apparatus. Thereby, a central characteristic of this style-one of its affects rooted in self-fascination-lay in the relative inconsequentiality of a given speech's content. According to Ernesto Laclau, ideology is animated by the presence of an "empty signifier" at its very heart. ${ }^{21}$ Indeed, an analysis of the contents of speeches reveals their "fictionalism"22 and semantic redundancy. Furthermore, it points to what Hannah Arendt termed, rightly and clairvoyantly, as "totalitarian movements' addiction to motion." Thus, according

18. "[P]arteiamtlichen Aufklärungs- und Rednerinformationsmaterial." Ibid., p. 30 (my translation). See also R.L. Buytwerk, "Die nationalsozialistische Versammlungspraxis. Die Anfänge vor 1933," in Diesener and Gries, 1996.

19. "Die erste Aufgabe der Propaganda ist die Gewinnung von Menschen für die spätere Organisation, die erste Aufgabe der Organisation ist die Gewinnung von Menschen zur Fortführung der Propaganda." Hitler, 1939, p. 654.

20. "Kunst der Gemeinschaftsbildung" and "dann gefährdet das Verstummen der Stimme die Existenz der Hörgemeinschaft." Hadamovsky, 1933, p. 21 (my translation).

21. Ernesto Laclau, "Was haben leere Signifikanten mit Politik zu tun?" in Emanzipation und Differenz, Wien, Turia und Kant, 2002.

22. Jean-Luc Nancy and Philippe Lacoue-Labarthe, The Literary Absolute. The Theory of Literature in German Romanticism, Albany, State University of New York Press, 1988. 
to Arendt, totalitarian movements do not rely on content-driven decisions and "are only able to sustain themselves as long as they stay in motion, putting everything around them into motion also."23 The Nazis' propagandistic and vocal performance strove to incorporate the movement's precarious and performative identity at all times. The movement, it might be said, can only remain a movement in motion for as long as it continually constitutes and propels itself through the mobilizing power of the voices of its speakers.

Until 1934, a unifying, binding propaganda concept had failed to emerge despite both the party's successful phonocentric organization and the emergence of a party mythology. Rather, there existed a range of diverse, and even incompatible, concepts of leadership: Hitler advocated for a form of "sentiment propaganda" that relied on mass speeches, which he considered an aesthetic form of art akin to film or painting, while Goebbels defended "action and attack propaganda" with a disciplinary function. Strasser's entourage, in turn, campaigned against a form of propaganda which would aim exclusively at the mobilization of sentiment and whose reliance on modern advertising psychology called for rejection on the basis of its blatant "Americanism." In reality, however, the myth of the NS-propaganda's inescapable omnipotence, which had first been orchestrated by Goebbels but continued to live on well after 1945, relied less on facts than on the nation's exonerating repertoire of repression, made manifest through a failure to oppose or stand nostalgically before the NS without being seduced by it in return. ${ }^{24}$

In no way did the NSDAP develop in a linear way consisting, for instance, in a successful application of the concepts outlined in Mein Kampf. This very suggestion in itself would have constituted an instance of propaganda and thus remained the privilege of the Propagandaminister. Indeed, Hitler's ideas and the party's day-to-day activities depended rather too heavily on tactical questions, diverging target audiences and specific political interests. Thus, in spite of the party's internal condemnation of such practices, decisions would generally be reached according to trial and error, while satisfaction polls were used as a

23. "Bewegungssüchtigkeit totalitärer Bewegungen" and "die sich überhaupt nur halten können, solange sie in Bewegung bleiben und alles um sich herum in Bewegung setzen." Hannah Arendt, Elemente und Ursprünge totaler Herrschaft [1955], Munich, Piper, 2000, p. 658 (my translation).

24. Gerhard Voigt, "Goebbels als Markentechniker" in Warenästhetik. Beiträge zur Diskussion, Weiterentwicklung und Vermittlung ihrer Kritik, Frankfurt, Suhrkamp, 1975, p. 231-260. See also Paul, 1992, p. 8. 
measuring stick for the party's activities. ${ }^{25}$ Within this context, the party's functioning might best be accounted for in terms of a looping effect, based on the repartition of agency, wherein propaganda is seen to shape expectations just as it is shaped by them in return. It must be emphasized that Hadamovsky was not expressing himself metaphorically when he discussed the way in which speakers heard themselves in the audience's voice as much as the audience seemed to take an active part in their speeches. ${ }^{26}$

With this concept of the singular voice, Hadamovsky also associated the idea, however fictional, of un-alienated speech, wherein the voice comes to be modelled as an agent of authenticity within mass communication. Hadamovsky was an opponent of "cold media," such as film and radio, but also of the press at large and broadsheets in particular. He argued that these media did not allow for the type of unmediated contact whereby an individual might melt into the larger "soul of the mass," making it possible to "trigger an action" in the process. Even if the "cold media" were to "reach their highest accomplishment in their simulation of reality," they nonetheless allowed the spectator to maintain an "interior distance." ${ }^{27}$ Such a distance, however, was regarded as highly disruptive by a regime whose functioning relied primarily on societal dedifferentiation, direct experience and the construction of communal experience.

In effect, Hadamovsky's argumentation presented a reaction to a state of affairs which was specific to the media-political landscape of the late 1920s: due to the growing proximity between state and broadcasting services at the time of the Weimar Republic, the central medium of NS propaganda had remained practically inaccessible. Even though Strasser and Goebbels had been allowed to speak on the radio for the occasion of the presidential elections in July 1932, the party's central speaker, Adolf Hitler, remained unheard until February 1st, $1933 .{ }^{28}$ While the press covered his greatly popular campaign appearances, which were frequently characterized by vocal excesses-Hitler routinely spoke for several hours on end-his voice could only be experienced through direct participation in those ritualistic speaking enactments. As a result, mass speeches became the

25. Heinz Boberach, Meldungen aus dem Reich 1938-1945. Die geheimen Lageberichte des Sicherheitsdienstes der SS, Herrsching, Pawlak, 1984.

26. Hadamovsky, 1933, p. 21-23.

27. "Vorspiegelung der Wirklichkeit einerseits höchste Vollendung erreichen." Ibid., p. 46 (my translation).

28. Ansgar Diller, Rundfunkpolitik im Dritten Reich, München, Deutscher Taschenbuch Verlag, 1980, p. 63. 
most effective tool for the pursuit of Hitler's goal to let his voice be heard, quite literally, by as many people as possible.

Naturally, the NSDAP had attempted to involve a range of media in its campaign. Thus, the poster campaign for the party and its representatives was successful, while the party's commercial films, due to their lack of mise-en-scène, failed to convince audiences and went entirely unheeded - a state of affairs which would only be altered by Leni Riefenstahl. Similarly, due to the limited public efficiency of phonographic recordings and their confinement to the living rooms of party members, the pressing of records failed to create the impact anticipated by the party. Furthermore, it must be assumed that, up until 1932, the NSDAP was suffering from a "chronic lack of financial means-indeed, no source here analyzed allows a financial trail leading back to industry donations to be traced. Instead, propaganda was being funded primarily through donations made by party members themselves, whereby entrance fees to mass events showcasing Hitler and Goebbels formed an important source of financing." 29

It is precisely at this media-political intersection that the loud/speaker apparatus' operating range situates itself: starting in 1928, the NSDAP became the first party to use this new technology, ${ }^{30}$ which uniquely allowed for an efficient way of directly addressing mass audiences. This mode was to become one of the principal conditions for the party's subsequent electoral successes. In fact, the loud/speaker was more efficient than broadcasting technologies were at producing the "contact creation" and "triggering of action" outlined in "cold media" theory: the loud/speaker successfully countered the distended communication characteristic of mass media without, however, making mass address impossible. Within the performative scenarios of mass address, it was the voice, separated from the speaker's body through electro-acoustic transformation, which came to draw attention to the dimension of physical presence inherent to mass communication. In this manner, the voice constituted a space of perception which obliterated the spatial distension at work between the physically present voice and the mass addressed audience. Through this device, the mass medium's

29. “[...] chronischem Geldmangel litt. Keine der ausgewerteten Quellen lässt eine Finanzierung durch Industriespenden erkennen. Vielmehr wurde die Propaganda durch NS-Spenden selbst finanziert, wobei Eintrittsgelder für Massenveranstaltungen, auf denen Hitler und Goebbels sprachen, eine wichtige Finanzierungsquelle darstellten." Jürgen Falter's preface to Paul, 1992, p. 8 (my translation).

30. Joseph Goebbels, Aufzeichnungen 1924-1945. Die Tagebücher von Joseph Goebbels. Sämtliche Fragmente. Band 2, Teil 1, Elke Fröhlich (ed.), Munich, Saur, 1987, p. 187. 
technological performance was connected to a form of "communication within the space of multifaceted perception." 31

For Hadamovsky, and Hitler equally, the mass took the shape of a "conglomeration" characterized by "lability, flexibility and explosiveness," a crowd in which "the individual remained elusive." ${ }^{2}$ Therefore, an immense effort of miseen-scène was necessary to translate the crowd's lability into stable voting intentions: it was only through a differentiated aggregated enactment of the voice that the improbability of its addressing power could be significantly reduced.

\section{LOUD/SPEAKER AS APPARATUS}

A review of the NSDAP's understanding of propaganda clarifies the loud/speaker's function as a media device which held integrating and consolidating functions for the NS political system. Notwithstanding the fact that the party's propaganda actually failed to address an overwhelmed audience effectively, the loud/speaker contributed to establishing the NS system's power: as a central media device of propagandistic communication, the loud/speaker restructured space both topographically and temporally. The following examples demonstrate how, through the specific development of the loudspeaker during the time of National Socialism, an omnipresence of the voice, and thus a virtual restructuring of space, were achieved. These, in turn, led to a far-reaching restructuration of existing political and communicational spaces.

As early as the 1932 election, titled "Hitler over Germany," the NSDAP deployed its mass communication program in the form of a technological media offensive. Within just a few weeks, this offensive connected the use of the loudspeaker with a program of mobility, which acted to annihilate spatial and temporal distances and to expand political spaces of resonance. In the course of 200 mass events taking place across the Reich, the party addressed over ten million people, according to NSDAP sources. This mass audience's aesthetic fascination with the new forms of vocal performance is, in fact, barely comprehensible for us today. ${ }^{33}$

Within this context, the apparatus demonstrated its effectiveness primarily through the fact that, within the shortest lapse of time, political space became

31. Niklas Luhmann, "Einfache Sozialsysteme," Zeitschrift für Soziologie, vol. 1, 1972 , p. 51-52.

32. Ibid., p. 21.

33. Heinrich Hoffmann and Josef Berchtold, Hitler über Deutschland, München, Eher, 1932, p. 3. 
a space for possible mass address. In turn, this space was constructed as an expanded temporal and topological acoustic space and subjected to a temporal pattern of its own making. Travelling propaganda commandos prepared individual municipalities for the arrival of the speakers from loudspeaker trucks. Other parties, specifically those on the left, restricted themselves to short appearances by speakers who would address the audience from its midst or from marked speaker positions, usually by relying solely on megaphones and without the help of amplification devices. The NSDAP, on the other hand, began by enveloping selected municipalities in a texture of sound which typically lasted for several days on end. It then proceeded to further orchestrate a sonorous and topologically expanded acoustic space-entirely unknown to its audience beforehand-which would serve as a space of resonance for the expected speaker and his audience. Interested parties from further away were transported to this acoustic center by rented trucks, special trains provided by the Reichsbahn, and privately organized bus and bicycle convoys from all parts of the country. Lufthansa provided an airplane for the speaker, so that several far-removed venues could be reached within a single day.

Arriving by air over the place of assembly, Hitler acted as an "icon of modernity"; an aura which was only amplified through his reliance on the most modern of loudspeaker technologies. The first use of loudspeakers in Germany dates back to $1924,{ }^{34}$ and was immediately followed by one of the first great test assemblies organized by engineers of the company Telefunken in a "huge car showroom at the Kaiserdamm" in Berlin, ${ }^{35}$ which sought to investigate how "the enormous dimensions of a hall come to be dominated entirely by a single human voice." ${ }^{36}$ Over the next ten years, the technology was further developed and, parallel to the psychoacoustics of interior spaces, the project of "filling the exterior with sound" came to stand continuously at the center of developments to come. In the heyday of ELA Studios, a subsidiary of Telefunken, the company's young workers, fascinated with technology and seduced by the new work opportunities offered by the construction of loudspeakers, built a unique system: "Telefunken's large-scale loudspeakers were instrumental in the triumphal march of National Socialism," states a factory pamphlet from 1934, "because the present unity of our people

34. Ralf Ehlert, "Public-Adress-Strategien von 1919-1949" in Daniel Gethmann and Markus Stauff (eds.), Politiken der Medien, Zürich and Berlin, Diaphanes, 2005, p. 326.

35. Epping-Jäger, "Eine einzige jubelnde Stimme," 2003, p. 151-152.

36. "[W]ie die riesigen Dimensionen eines Saales vollkommen durch eine einzelne menschliche Stimme zu beherrschen.” H. Gerdien, "Über klanggetreue Schallwiedergabe mittels Lautsprechern” in Telefunken-Zeitung, vol. 8, n ${ }^{\circ}$ 43, 1926, p. 36-37 (my translation). 
was consolidated through thousands of meetings and ultimately achieved in the powerful rallies of the last few years." ${ }^{37}$ Due to the company's interests as well as to engineers' political inclinations, which were further underlined through their collaboration with NSDAP loud/speaker experts, top of the line systems were only lent out to the NSDAP, and never to left-wing parties. The technical structures and psychoacoustic facilities required for the installation of loudspeakers were organized on site by both NSDAP and company experts. Those NSDAP experts who were particularly successful were fast to ascend in the party's hierarchy: thus, Hermann Schäfer from Lemgo was promoted to the position of ReichslautsprecherFührer, while Leopold Gutter, as secretary of state for the Reichspropagandaministerium, is famous for his orchestration of the Olympics, amongst other events. Whenever possible, speaker spaces were established out in the open, or in sports arenas and other pre-existing spaces of resonance. "The loudspeaker," Emil Dovifat wrote, "turns open skies into an assembly tent."38

The speeches themselves, in turn, were broadcasted into public space as well as into halls and tents rented for this particular purpose. Hitler's addresses, which were typically programmed in the evenings, inevitably took place after calculated delays of several hours, thought to increase audiences' liability to be more readily influenced by the address; in addition, the long delays left sufficient time to set the stage for the Führer's arrival. ${ }^{39}$ The "Führer's speeches" (FührerReden) were transmitted both into interiors and into public space: according to a journalist hired by the NSDAP, "the Frankenhalle had been sold out for days, so that 14 loudspeakers had to be used to broadcast the Führer's speech to the tens of thousands huddled together on the outside. [...] Sentence after sentence resonated into the cold night, sinking deep into the hearts of listeners." ${ }^{\prime 40}$

37. "Die Telefunken-Großlautsprecher waren Helfer auf dem Siegeszug der nationalsozialistischen Idee denn die heutige Einheit unseres Volkes wurde zusammengeschweißt in Tausenden von Versammlungen und schließlich vollendet in den machtvollen Kundgebungen der letzten Jahre." Telefunken-Werbeprospekt, Berlin, Historical Archive, Technikmuseum, 1934, Archival Number GS 5179 (my translation).

38. Emil Dovifat, Rede und Redner. Ihr Wesen und ihre politische Macht, Leipzig, Bibliographisches Institut, 1937, p. 15.

39. Epping-Jäger, "Eine einzige jubelnde Stimme," 2003, p. 153-155.

40. "Die Frankenhalle war seit Tagen ausverkauft, so mussten 14 Lautsprecher die Rede des Führers zu den Zehntausenden tragen, die sich im Freien zusammenballten. [...] Satz um Satz dröhnte in die kalte Nacht, senkte sich in die Herzen." Hoffmann and Berchtold, 1934, p. 23 (my translation). 
Thus, the loud/speaker transformed the rooms characteristic for the meetings of the NS-movement into veritable spaces of resonance. Within those spaces, the voice of the speaker was staged as a vox magna on the one hand and, on the other, as a voice able to interact with members of the community in an unmediated way through its unique status. From the speaker's perspective, this effect was only made possible by technical voice transmission. Furthermore, it could only unfold within the area of tension between feedback processing and the selfinduction of the speaker, as well as through the logic of pseudo-direct interaction. Indeed, through the loud/speaker's feedback mechanism, the speaker was able to hear himself with a slight delay, his voice blown up by the force of mass resonance. Since loudspeakers consistently transmitted acoustic signals with a slight delay, ${ }^{41}$ the speaker's direct perception of himself came to be overwritten through a technologically mediated, temporally delayed resonance, which adopted the form of the voice as it came to be heard by all parties present. As a result, the voice, separated from the body through the microphone/loudspeaker configuration, re-entered the body of the speaker by taking a collective, ratified form. Through the combination of microphone and loudspeaker, the voice was staged as paradoxically near and far at the same time: equally present to itself and technically distant, the voice became a simultaneous manifestation of both mass address and "intimate communication within a space of multifaceted perception.” It is through this synthesis between a techno-acoustic format and new forms of performative mise-en-scène, that the Nazis' vocal politics came to be revealed in all their effective power.

\section{LOUD/SPEAKER SCENARIOS AFTER 1933}

It is a given that further mass communicational scenarios were generated by way of the specific structures of the loud/speaker device, which were conditional upon the deployment of state power. Consequently, it is not surprising that, after January 30, 1933, great techno-medial enactments not only multiplied themselves, but also acted to further differentiate the loud/speaker apparatus. This process was closely tied to a phase of intensive experimental trials which focused on new communicational structures such as, in particular, the networked inclusion of other media and the creation of media unions.

For instance, the celebrations of May 1, 1933 were organized by the NSDAP as a collection of media-acoustic events, which took place on the Tempelhofer Feld in Berlin. For several years, left-wing parties had demonstrated and fought 
for the introduction of an annual "Work Day." In the very first year of its appointment, the NS appropriated this event by expropriating the Left in semantic and symbolically political terms. The first act consisted in the negation of the Left's internationalism: as a result, the "Work Day" was renamed "Day of National Work" and was organized exclusively by the NSDAP. For several days, the event's official beginning at midnight had been advertised throughout the city of Berlin with newspaper articles and radio advertisements, broadsheets, route planners, and the announcement of refreshment points. At midnight sharp, the celebratory convoys, which had been organized in advance, left their respective areas and set course for Berlin. Over the course of the day, workers and youth, divided into columns of 60,000 persons each and arranged into a star-shaped formation, marched onto the Tempelhofer Feld. Military marches resonated from horn loudspeakers while large loudspeakers transmitted the speeches of NS notables into the city's space. In the meantime, radio sets had been placed in open windows and doorways, and these were used to broadcast live reports on the columns' progress toward the Tempelhofer Feld. The global effect was one of simultaneous enactment in which two million participants listened to both themselves and each other as they engaged in the very act of marching. ${ }^{42}$

At the site of the Tempelhofer Feld, loudspeakers were used to communicate standpoints to aircrafts used to photograph the event and, amongst other things, to keep track of the number of participants arriving on site. Professional groups had been prompted to wear work-related clothing and, within specific parts of the perimeter, the traditional pleasures of the worker movement were explicitly permitted: picnics, gymnastics performances, as well as shawm parades, hot dog stands and draymen offering their goods for sale. In order to turn simple visitors into fully-fledged participants, the NS exacerbated the experiential character of large-scale events. For this purpose, an experience-based program had been developed which consisted of live and semi-live events. This program integrated tried and true forms of political enactment, as well as their semantics, which stemmed from the workers' movement, in order to reconstruct them medially through the device of the loud/speaker. Thus, the miners who played as part of a shawm band on the site were also able to hear themselves from the air, along with a commentator's appreciation of their performance (the commentator being a star reporter positioned in an airship which was aptly named "Graf Zeppelin"). The monumentality of the mass march and the image of the mass formation, which escaped the individual participant's grasp as they could only be perceived 
in fragmented form, were thus made available to them through this running commentary "from above." If the shawm players listened carefully, they would be able to hear themselves again over the course of the day as the report was re-transmitted from the airship as part of a radio program through large loudspeakers on the Tempelhofer Feld. All this was only made possible through the first-time deployment of the newest media technologies: the reports were cut to wax on the airship in order to be broadcast as part of an 18 -hour nationwide radio event; the first event of this scale in the history of radio. ${ }^{43}$

Until February 1933, the NS had subsisted without the radio. Goebbels, who valued live events, actuality and presentness, noted in his diary: "Radio in the house! The German citizen relinquishes his work and fatherland for the radio! Radio! The modern medium of embourgeoisement! Everything in the home! The ideal of the bourgeois!"44 Now, in preparation for the May 1st celebrations of 1933, it was decided that the radio would increasingly come to occupy the function of expanding distribution within the loud/speaker framework. By the end of January 1933, it had become clear that Adolf Hitler would not make for an effective radio speaker: on February $1^{\text {st }}$ his voice had first been broadcast across the Reich and it had disappointed audiences. Indignant listeners failed to perceive his voice's all-encompassing and convincing power; instead, all they heard was a series of mumbles and slurs. Hitler's voice was perceived to lack energy and listeners found it disagreeable in its evocation of barrack yards. ${ }^{45}$ Hitler was no radio announcer, and this was emphasized by the fact that his rhetorical power of suggestion was only able to unfold through an already imagined logic of pseudo-direct interaction with the audience. This fact was further emphasized by the Tempelhofer Feld event: the party's strategists, working hand in hand with electrical companies, had installed huge amplifying systems alongside a network of 100 large loudspeakers in order to ensure that no "silent zone" would remain within the space. In the event of a glitch, "they would instantly have procured large loudspeakers and activated them..." ${ }^{\prime 46}$ According to Eduard Rhein's comments, made

43. Transcript of the broadcast 1. Mai 1933, Wiesbaden, German Radio Archive, Archival Number C 12160 .

44. "Radio im Hause! Der Deutsche vergisst über Radio Beruf und Vaterland! Radio! Das moderne Verspießerungsmittel! Alles zu Hause! Das Ideal des Spießers!' hatte Goebbels, der auf Präsenzveranstaltungen, Aktualität und Dabeisein setzte, in sein Tagebuch notiert." Goebbels, 1987, p. 47 (my translation).

45. Diller, 1980, p. 62-63.

46. "[D]a wäre sofort ein Großlautsprecherwagen herbeigeschafft und in Betrieb genommen worden..." Eduard Rhein, "Mit der Kraft von 5000 Stimmen. Die 
on the day after the event, the aim has been to "dominate a space of almost 50,000 square meters with a single voice $[. .$.$] and to render each and every word$ intelligible, to transmit the smallest tremors of this voice." ${ }^{47}$ Hitler addressed the crowd from a 10 meter podium and he spoke in such a way that any sense of distance between speaker and listener was immediately forgotten, according to another "reporter": "it is as if the souls of these 1.5 million [participants] were to unite themselves into a tremendous apparition, an outcry, a movement, a shape looming large above everything." 48

The failure of the transmission of Hitler's voice through the radio, and the success of that same voice at the Tempelhofer Feld, led NSDAP strategists to avoid addressing the anonymous collective of radio listeners directly from the studio. Instead, they sought to address radio audiences indirectly, by following the example of a previously successful speech given within the framework of a mass event. Rather than hearing only the Führer's voice, radio audiences now heard the speaker's voice as amplified through the affirmative resonance of a directly present mass public. From this point on, within the framework of the "loud/ speaker" apparatus, broadcasting took on the medial role of disseminating effective vocal enactments. Whenever possible, Hitler's voice would no longer travel nakedly through the airwaves; instead, it would remain an embedded voice, sheathed in the mass acclamations in which radio audiences were encouraged to participate.

In conclusion, the events of May 1, 1933, could be summarized as an occasion through which this far-reaching media matrix was tested and tried in order to connect the possibilities for the construction of "on site" communal experiences with the possibilities for universal address offered by broadcasting technologies. The idea for such a connection can also be found, for the May festivities of 1934, in the technical design offered by ELA Studios loudspeaker experts, who had developed a new transmission technology, the so-called "mushroom

Großlautsprecher-Anlage für Hitlers Rede auf dem Tempelhofer Feld-Eine Glanzleistung der Technik." in Berliner Morgenpost, May 3, 1933 (my translation).

47. "[E]inen Raum von fast 500 ooo Quadratmetern mit einer einzigen Stimme zu beherrschen [...] jedes einzelne Wort verständlich zu machen, jedes kleine und kleinste Beben dieser Stimme zu übermitteln." Ibid. (my translation).

48. "Es ist als müssten sich die Seelen dieser 1,5 Millionen [Teilnehmer] zu einer gewaltigen Erscheinung vereinen, einem Aufschrei, einer Bewegung, einer alles überragenden Gestalt." Hans Wendt, Der Tag der nationalen Arbeit. Die Feier des 1. Mai 1933, Berlin, E. S. Mittler, 1933, p. 27 (my translation). 
loudspeaker," in close collaboration with propaganda experts. ${ }^{49}$ Those speakers were easier to transport than large loudspeakers and could be installed anywhere; they were designed to project over a 50 meter radial space of echo and resonance which was kept free of interference. This space provided an ideal public form of experience, termed "community reception," wherein the loud/speaker apparatus could unfold. The term "community reception" refers to the media reception that occurs when listeners assembled around a "mushroom speaker" are addressed with precision. Through auditors' respective perception and surveillance of one another, the above can be regarded as an example of Deleuze's society of control.

Furthermore, broadcasting had established itself as a suitable venue for the loud/speaker apparatus. The large auditoriums, spreading out before the radio transmitters which bore the task of the transmission of public space, demonstrated the ways in which community reception represented an ideal, radiodependent form of discourse from the NS's perspective. Community reception limited the loss of control which might have resulted from the difficulty of addressing an anonymous, collective audience whose listening habits were virtually impossible to direct. Thus, the central traits which were to characterize the loud/speaker for a number of years to come first emerged: they were made apparent by the juxtaposition of live events with the mixture of live and semi-live interventions constitutive of radio programs at the time, as well as through the markedly positive response these received. Ultimately, they would culminate in the medial construct of new, collective spaces of experience, which represented an "actualism of presentness" made evident through a choreography of tension between stillness and movement. However, in its attempt to organize community in a mass communicational way, this actualism remained dependent on iterative processes. Just as propagandistic slogans had to be constantly shared and repeated in order to remain relevant, so the regular affirmation of the people's community had to be rehearsed as a medial mass experience.

As a result, the discursive form of the "community reception" traverses the era of National Socialism in the manner of a recurring theme: in 1934, plans began for the exploitation of the entire surface area of public space by a network of loudspeaker columns (Reichslautsprechersäulen) which were to

49. Telefunken. Tradition und Technik, publicity prospectus, Berlin, Historical Archive of the German Technikmuseum, no archival number, 1937. 
"ensure immediate access to the entire population within a single instant."50 In 1936, a publicity pamphlet published by the electrical industry reported on on-going successes: according to this source, several cities, communities, schools and businesses had invested in loudspeaker systems in order to comply with requirements which stipulated that "important broadcasts [...] should benefit all national comrades by taking the form, if possible, of a community reception." ${ }^{51}$ Soon thereafter, NS propaganda made use of loudspeakers and broadcasting systems in order to stage impressive manifestations of unity: as the Preußische Zeitung reported, on the occasion of Hitler's appeal to the "entire German nation, [...] all working Germans would be assembled around loudspeakers for a community reception to mark this historical moment [and, as it happened], after a signal [sounded], the entire Reich [maintained] a full minute of traffic standstill." 52

The final, and potentially most paradigmatic example of the establishment of the loud/speaker as media device emerges with the example of the so-called Reichsautozug. Requested by the NSDAP and built in the mid-193os by the car-manufacturer Magirus, the largest auto-train of the world at the time, constructed of 4 convoys consisting of 20 buses and trucks each, was first put to use in $1936 .^{53}$ Reaching a total length of more than 3 kilometres, the autotrain's central task consisted in its ad hoc ability to both organize and broadcast mass addresses and events. It was involved in the Nürnberger Parteitage and in the Olympic Games, amongst other events, but it also participated in isolated addresses, the inauguration of motorways, or the Anschluss with Austria, which took place on the Heldenplatz in Vienna. In a nutshell, the Reichsautozug is best

50. "[D]ie augenblickliche akustische Erfassung der gesamten Bevölkerung." Bundesarchiv, Section NS 10/46 (my translation).

51. "[W]ichtige Funkübertragungen [...] allen Volksgenossen zugute kommen und nach Möglichkeit zu einem Gemeinschaftsempfang gestaltet werden.” TelefunkenWerbeprospekt, 1936 (my translation).

52. "[A]n das ganze Deutschland [...] sämtliche schaffenden deutschen Menschen in dieser historischen Stunde zum Gemeinschaftsempfang an den Lautsprecheranlagen versammelt sein [...] ein Signal zu hören, auf das hin im gesamten deutschen Reich eine Minute Verkehrsstille." Author unknown, Preußische Zeitung, March 18, 1936 (my translation).

53. Cornelia Epping-Jäger, "Stimme. Die Spur der Bewegung," in Gisela Fehrmann, Erika Linz and Cornelia Epping-Jäger (eds.), Spuren Lektüren. Praktiken des Symbolischen, Munich, 2005, p. 133-151. See also Horst Hinrichsen, Reichsautozug „Deutschland“ und Hilfszug „Bayern“. Die beiden größten Autozüge der Welt in den zoer Jahren, WolfersheimBerstadt, Podzun-Pallas, 1998. 
understood, in terms of the loud/speaker, as a medial aggregate which conferred flexibility, autarchy and topological ubiquity upon acoustic propaganda spaces in the making.

The center of the "train" was made up of a speaker and director's car, which contained a 6 meter retractable podium, mobile arenas for the audience, and a sophisticated loudspeaker system. In addition, the convoy carried loudspeakers affixed to the car's roof, as well as 150 mushroom loudspeakers which could transform any portion of motorway into an ad hoc space of meeting and resonance, or sonorize entire sections of the route as needed. Logistically, the speaker's car was framed by a range of other cars which contained radio, long distance and transmission equipment, as well as film cameras for the shooting of newsreels. Finally, the last car had the capacity to provide stew for 10,000 participants. Thus, it is this form of techno-medial ensemble which allowed for the emergence of the ring connections which were to become characteristic of the NS. The entire train could be divided into a range of single trains and cars, which could participate in parallel events occurring in different places at the same time, and it further possessed the ability to organize and cater to mass events involving up to 30,000 persons. Thereby, discrete events would come to be connected to each other through the auto-train to such an extent that they formed a potential space of resonance. As these examples make clear, the invention of the loud/ speaker by the NS division of propaganda communication did not only present a technological innovation in terms of the emergence of a single medium, but also functioned as a fully-fledged medial apparatus. In this way, the device's primary achievement could be seen to reside in the multimedial interconnection it created between temporal dynamic and topographic organization and which, in turn, was to significantly transform communicational spaces.

It is noteworthy that the loud/speaker did not simply serve to create a new level of propaganda through its overpowering of mass audiences according to strategic principles. Instead, in order to achieve communicational success, it remained dependent on audiences' readiness to create a space of resonance. Bound up with the loud/speaker apparatus, the concept of use and gratification, systematic market research and the constant backlashes of mass communication were part of a set of NS practices which sought to compensate for the lack of democratic forms of public resonance within the party's own structures. From this perspective, the regular news messages from the Reich, ${ }^{54}$ which were directly commissioned by state security (Sicherheitsdienst der SS), occupied the function 
of putting NS leaders in the position of replacing public criticism with insights into the population's present and emerging preoccupations. In contrast with the Weimar Republic or even the Kaiserreich, the connection between popular culture and NS propaganda had the effect of "filling the national comrade's [daily routine] with suspense, adventure and a certain sense of cosmopolitanism." ${ }^{155}$ However, the fact that Germans "bought into this mode of gratification by accepting readily, as an entirely coherent communication system, the themes and propaganda put forward by the NSDAP's propaganda division, ${ }^{, 56}$ is only true for the so-called model of "integration propaganda," which was to last until the beginning of WWII.

In the first, successful years of the war, the loud/speaker apparatus operated with well-known efficiency: for now, it remained the NS propaganda's possibly most successful product as it built upon the very "Führer myth" which had contributed to systematically elevate Hitler's persona over the degradations of dayto-day politics..$^{57}$ As part of this effective propaganda image, and in spite of his own personal inclinations, Hitler the speaker had to be presented as a "Führer of Peace." Recent research showed that this image of the Führer was as much a product of the people, as it had been projected onto the people for purposes of propaganda. Thus, it was both a result of NS propaganda and of the people's political understanding and expectations. ${ }^{58}$ As a result, the Führer's alleged radical change of positions in respect to the question of war led to his first significant loss of popularity. ${ }^{59}$

In response to the growing threat of a destabilization of the Führer myth, the NS system reacted with an all-encompassing staging of war triumphs, organized by way of the loud/speaker within media networks. A prime example is the distribution of four addresses held by Hitler at the end of 1940 and the beginning of 1941. These had the aim of establishing a connection between past triumphs and

55. "[E]infachen Volksgenossen spannender, erlebnisreicher und in mancher Hinsicht kosmopolitischer zu gestalten.” Thymian Bussemer, Propaganda und Populärkultur. Konstruierte Erlebniswelten im Nationasozialismus, Wiesbaden, Deutscher Universitäts-Verlag, 2000, p. 96 (my translation).

56. Ibid.

57. Behrenbeck, 1996.

58. Ian Kershaw, Der Hitler-Mythos. Volksmeinung und Propaganda im Dritten Reich, Stuttgart, Deutsche Verlags-Anstalt, 1980, p. 22.

59. Ibid., p. 13. See also Martin Broszat, Der Staat Hitlers. Grundlegung und Entwicklung seiner inneren Verfassung [1969], Munich, Deutscher Taschenbuch Verlag, 2000, p. 432-433. 
the suggestion of a grandiose final victory, brought about by the Führer himself. The speeches were held before a mass audience and broadcast on the radio after having been introduced by Goebbels. Following their transmission, they became the object of editorials and home stories. In parallel, cinemas were showing the feature film Wunschkonzert (Request Concert, 1940, Eduard von Borsody), which soon became a blockbuster. Consequently, Hitler's series of addresses provoked a surge in popularity: even if the references were indirect, the film revealed several levels of the loud/speaker apparatus' mode of functioning. In the opening sequence, images from Riefenstahl films show Hitler as a celebrated orator. The film's narrative episodes, in turn, cite central themes of integration-propaganda, such as the levelling of social hierarchies for the benefit of a people's community, or the aestheticization and construction of experiential universes within ring connections. Simultaneously, the film makes clear that the media system is indeed reflecting itself by bringing the apparatus into view: thus, the media are portrayed to cite other media, documentary film to quote live appearances and narrative films to reproduce documentary films, while the radio echoes community reception, radio-shows are shown to cite novels and war propaganda quotes its own transposition into narrative film.

The loud/speaker's change of function made its first appearance with the growing disequilibrium of the use and gratification system upon which it had been relying. With the advancement of the war, audiences' perception of reality began to separate from the semantics of propaganda; as a result, the loud/ speaker apparatus suffered a loss of resonance and perlocutionary effectiveness at the level of its integration and consolidation functions. As defeats began to outnumber victories, even party reporters came to acknowledge that the addresses "were no longer meeting with the same level of generalized approval they once received." ${ }^{60}$ The distance between word and belief, once heralded by propaganda strategists as the sign of an "interior reserve" toward the NS system took, for the first time, the shape of a mass reaction to a further series of addresses, whose announcements were soon overshadowed by current events. By Christmas of 1941, an SD-report alerted to a "low point in public opinion." ${ }^{\text {61 }}$ At the beginning of the year 1942, it was noted that many persons had "felt the need, once again, to hear the voice of the Führer in the hope of drawing renewed strength

60. "[N]icht mehr überall das erwartete Echo fanden." Kershaw, 1980, p. 224 (my translation).

61. "[E]inem Tiefstand der öffentlichen Meinung." Ibid., p. 216 (my translation). 
from it." ${ }^{62}$ Due to the changing military situation, Hitler had not spoken publicly in several months. Therefore, the NS propaganda system failed to utilize the so-far successfully realized possibilities of the apparatus in order to set in scene the Führer's voice as an instance of live communication bound up with mass communicational scenarios. Replacing the forms of mass communication which stemmed from public presentness and focused on the staging of community, radio became an increasingly preeminent mass medium whose effects were less controllable, with the exception of limitations imposed on programming. Thus, Hitler's downfall did not begin, as is frequently claimed by specialists, with the defeat at Stalingrad: in respect to the Hitler myth, the turning point began in 1942, with steadily growing, if hidden and subversively voiced, criticisms of the image of the Führer as a far-sighted, infallible and well-intentioned figure. These criticisms were a direct consequence of the disaffection of the loud/speaker apparatus which had occurred over previous months.

However, mirroring the apparatus' decreasing use within the Reich, the loud/speaker found renewed application potential beyond its borders: within the framework of so-called propaganda companies (Propagandakompanien), the loud/speaker came into use at the military fronts of a new field of operation. Through this migration of the loud/speaker from the civil and political spheres to the Reich's military borders, the Nazis' expectations of power, which had led to the party's initial shift toward the practice of a form of media politics, were transferred into the military realm. ${ }^{63}$

It thus becomes clear that the initial communicational phantasm of a nonalienated, charismatic Führer's voice-a voice addressing the communityevokes two central dimensions of medial "invisibility": the first is represented by the invisibility of the communicational mise-en-scène of the voice. It is known that the NS greatly controlled its visual appearance. However, that the same level of control should be ascribed to its acoustic appearance remains a largely underexplored proposition, even by contemporary historians, since the voice largely continues to function as a guarantee of authenticity. "Questions of mise-enscène," said Goebbels at a press conference for the Reich, "do not fundamentally

62. "[D]as Bedürfnis empfunden hatten, wieder einmal die Stimme des Führers zu hören und aus seinen Worten neue Kraft zu schöpfen." Ibid., p. 216-217 (my translation).

63. Cornelia Epping-Jäger, "LautSprecher-Passagen. Zu den Umbauten der Massenkommunikation vor und nach 1945," in Irmela Schneider and Cornelia Epping-Jäger (eds.) Formationen der Mediennutzung. Dispositive Ordnungen im Umbau, Bielefeld, Transcript, 2008, p. 17-41. 
belong in the public sphere." ${ }^{64}$ Indeed, it is likely that the same position held true for the acoustic orchestrations of the NS. For how else might we account for the fact that, until the present day, no documents have been found to support the acoustic and technical manipulations undergone by Hitler's voice?

The second dimension of medial invisibility points to the fact that media are routinely "erased" from the perception of their observers and users in so far that their functioning remains unproblematic. From this perspective, as a communicational and operational evidence-machine, the medial apparatus remained invisible. Not only as a medium geared toward its contemporaries, but also from the vantage point of a retrospectively reluctant historiographic analysis of the communication policies of the NS. As a result, the radio was put forward as a technical mass medium, characteristic for the NS, while mass announcements were barely considered in light of their constitutive technological and medial conditions. Instead, they were consistently reduced to the alleged charisma of Hitler's figure as a Führer/seducer. From the outset, however, phonocentricism, which was organized in terms of media and technology and remained characteristic of modes of mass address, long predated the NS's accession to the radio. Consequently, even after 1933, the loud/speaker-as-apparatus proved to be an ideal space of resonance and organization which successfully established itself as a mass medium on a par with voice-based radio while it also facilitated the inclusion of the radio within its larger operative network.

Translated from the German by Caroline Bem

64. "Regiefragen gehören grundsätzlich nicht in die Öffentlichkeit." Goebbels cited in Schmeer, 1956, p. 28 (my translation). 